"Impact of Islamic work values on in-role performance: Perspective from Muslim employee in Indonesia"

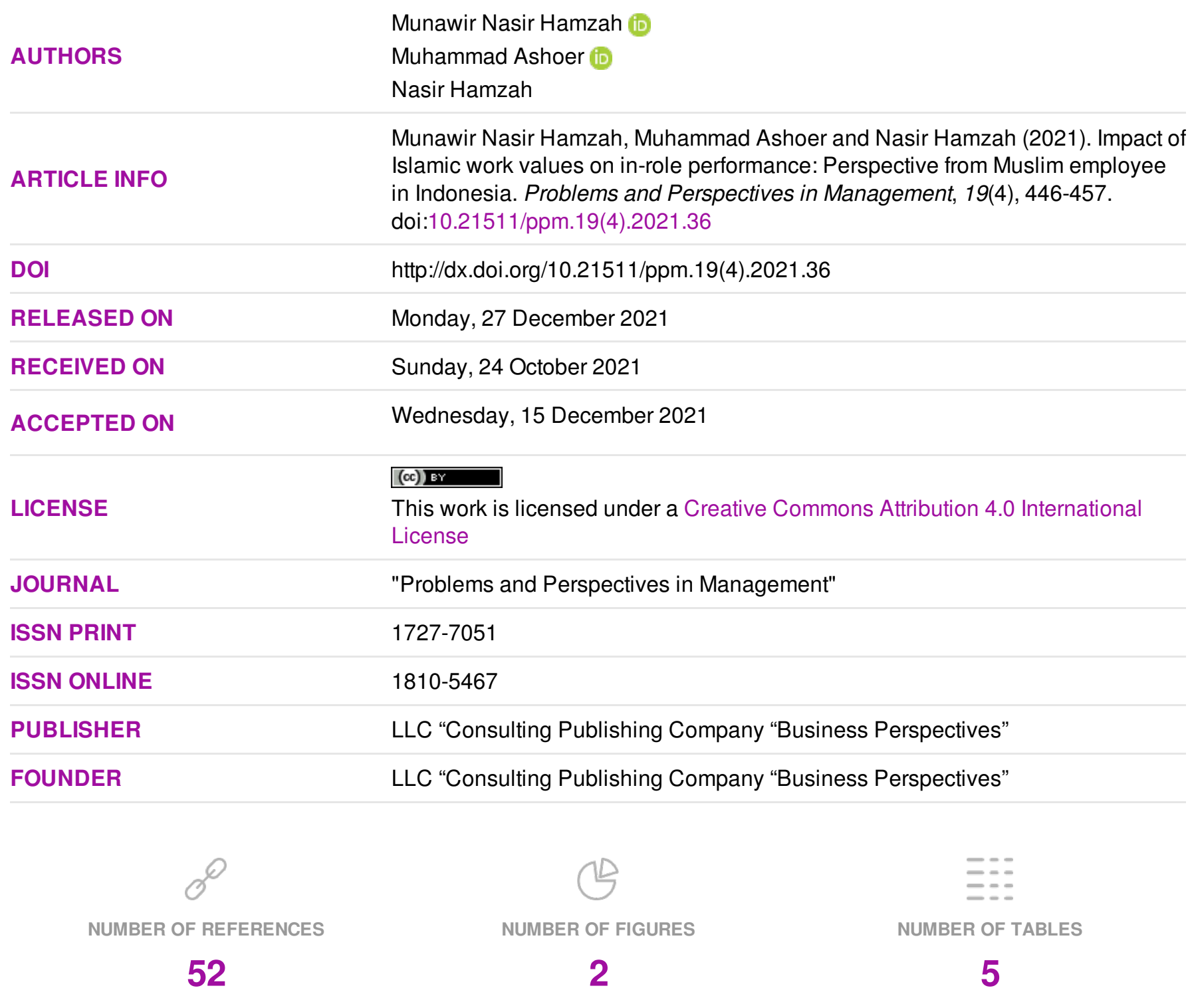

(c) The author(s) 2021. This publication is an open access article. 


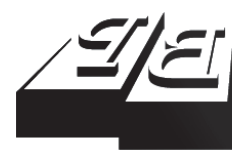

\section{BUSINESS PERSPECTIVES}

()

LLC "CPC "Business Perspectives" Hryhorii Skovoroda lane, 10, Sumy, 40022, Ukraine www.businessperspectives.org
Received on: $24^{\text {th }}$ of October, 2021 Accepted on: $15^{\text {th }}$ of December, 2021 Published on: $2^{\text {th }}$ of December, 2021

(C) Munawir Nasir Hamzah, Muhammad Ashoer, Nasir Hamzah, 2021

Munawir Nasir Hamzah, M.Sc. Assistant Professor, Faculty of Economics and Business, Muslim University of Indonesia, Indonesia. (Corresponding author)

Muhammad Ashoer, M.Sc., Assistant Professor, Faculty of Economics and Business, Muslim University of Indonesia, Indonesia.

Nasir Hamzah, Ph.D., Professor, Faculty of Economics and Business, Muslim University of Indonesia, Indonesia.
This is an Open Access article, distributed under the terms of the Creative Commons Attribution 4.0 International license, which permits unrestricted re-use, distribution, and reproduction in any medium, provided the original work is properly cited.

Conflict of interest statement: Author(s) reported no conflict of interest

Munawir Nasir Hamzah (Indonesia), Muhammad Ashoer (Indonesia),

Nasir Hamzah (Indonesia)

\title{
IMPACT OF ISLAMIC WORK VALUES ON IN-ROLE PERFORMANCE: PERSPECTIVE FROM MUSLIM EMPLOYEE IN INDONESIA
}

\begin{abstract}
Religious values are contemporary issues associated with employees' behavior in organizations, especially from the Islamic human resource (HR) management view. To address this issue, this study analyzed the influence of Islamic work values on engagement, job satisfaction, organizational commitment, and in-role performance of Muslim employees. Considering the potential spread of COVID-19, primary data was collected by distributing online questionnaire via emails and social media to 283 respondents in Makassar City, Indonesia, who fulfilled the predetermined sampling criterion. PLS SEM was employed to check the measurement and structural models of the SmartPLS 3.0 program. It was revealed that Islamic work values have a significant influence on engagement and job satisfaction and in contrast, insignificant on organizational commitment and employee in-role performance. In addition, a significant interrelationship between the 4 endogenous variables was confirmed, namely engagement, job satisfaction, organizational commitment, and in-role performance. Furthermore, it was found that several constructs mediate the correlation between Islamic values and in-role performance. The findings are essential to provide theoretical enrichment for future studies pertaining to the measured Islamic values and HR behavior. Practically, managers are capable to devise and select the most appropriate HR strategies for Muslim employee in a particular organization.
\end{abstract}

Keywords

\section{JEL Classification}

\section{INTRODUCTION}

Human resource management (HRM) has evolved through numerous stages ranging from prior obligatory jobs to personnel and contemporary management. Throughout the years, the understanding of Islam and its relationship with different management practices has been massively enhanced although the universal concepts and acceptance of human nature vary according to their specific faith, culture, and tradition (Wahab \& Masron, 2020). One of the frequently adopted constructs is the Islamic work values (IWV), defined as a personality attitude that gives birth to a deep belief that an individual's means of livelihood is not only to glorify oneself, rather, it is perceived as a manifestation of righteous deeds and is highly regarded (Wahab \& Masron, 2020). Considering that religious values are such a burgeoning issue, companies are deemed to incorporate and promote the spiritual aspects even though the system is rationally operationalized (Asutay et al., 2021). Interestingly, related studies have been carried out in Islamic countries, thereby driving organizations and management practices towards the framework of their internal faith (Mellahi \& Budhwar, 2010). 
The existing literature reveals that Islamic work values (IWV) are presently regarded as a fundamental topic in Islam research (Mohammad et al., 2015) and some studies have assessed the influence of IWV on HR behavior. Farid et al. (2017) claimed a positive effect of IWV on the engagement of healthcare employees in Pakistan. Likewise, Asutay et al. (2021), Gheitani et al. (2019), and Yousef (2001) also discovered that IWV significantly affects job satisfaction and organizational commitment in different business contexts. In Indonesia, inquiries by Hayati and Caniago (2012) and Miswanto et al. (2020) confirmed the importance of IWV on improving employee performance. Hence, it can be stated that an individual who trusts Islam and implements its values is more committed and satisfied with an organization and is likely to show better job performance.

In spite of its influential role, the preliminary studies have not particularly analyzed the existing gap between Islamic management theory and practices on behalf of the IWV and its impact on HR behavior, creating an empirical gap that needs to be verified (Miles, 2017). In addition, Gheitani et al. (2019) contend that IWV studies mainly focus on the normative aspects of the management, and the Islamic economy and banking topics consistently received the greatest coverage. As a result, understanding its potential role in determining HR behavior is still in the elementary stages. Therefore, to promote Islamic teachings and ensure it is accessible and widely learned for work-related aspects, the paper aims to empirically investigate the relationship between IWVs, employee engagement (ENG), job satisfaction (JS), organizational commitment (OC), and in-role performance (IRP). Moreover, the current study examines whether ENG, JS, and OC mediate the relationship between IWV and IRP. This study is essential to theoretically implicate the Islamic management field as it adapted the newest core items of IWV created by Wahab and Masron (2020). It may stimulate potential future studies. From a practical perspective, managers can refer to the novel IWV items as a foundation to improve employee engagement, satisfaction, commitment, and in-role performance.

\section{LITERATURE REVIEW}

\subsection{Islamic work value (IWV)}

The IWV is an essential aspect of a person's faith (belief) based on the Quran, the Prophet's words, and acts that have brought dignity and virtue to work (Ali \& Al-Owaihan, 2008). Similarly, it might be claimed that the IWV's prominent premise is that all human beings are obligated to perform positive rather than negative actions. Islamic values include morality, where all activities are per their ethics because this religion fails to recognize the dichotomy between mundane and religious affairs (Wahab \& Masron, 2020). The subsequent value is competition, which involves the need or ability to fairly and honestly compete with other employees as well as rely on the intention of fastabiqul khoirot (a race to achieve virtue) (Razimi et al., 2014). The IWV is an inclination that forms and influences the engagement and participation of its adherents at workplaces (Rana \& Malik, 2016). It views labor as a way to promote own interests financially, socially, and psychologically, as well as to maintain one's reputation, improve societal welfare, and confirm the beliefs (Ali, 2010). Moreover, it improves performance, for instance, work is interpreted as an elaboration of aqidah, a charity based on knowledge, or by imitating divine attributes (Budhwar \& Mellahi, 2010). Consequently, being productive at work based on religious understanding and responsibility is one of Muslims' characteristic personalities as they do not work to solely get paid or maintain their prestige.

Many studies examined the effect of IWV on employee behavior. The most popular one is Yousef (2001) who investigated its moderating impact on the relationship between organizational commitment and job satisfaction. The study analyzed the data from more than 400 Muslim employees in the United Arab Emirates (UAE) and revealed that IWV directly affects organizational commitment and job satisfaction and moderates the connection between these 2 constructs. Similarly, Gheitani et al. (2019), Nasution and Rafiki (2019), Hayati and Caniago (2012), and Sadozai et al. (2013) discovered positive and significant links between IWV, job satisfaction, and organizational commitment. Meanwhile, Athar et al. (2016), Farid et al. (2017), and Al-Shamali (2021) confirmed a significant and positive relationship be- 
tween IWV and employee engagement. Likewise, Miswanto et al. (2020) and Hayati and Caniago (2012) investigated the relationship between IWV and job performance and found a significant relationship between these constructs. Hence, the Islamic values need to be examined because it is related to the spiritual aspect of existence, which reflects the faith or Islamic aqidah regarding labor based on revelation and reason (Syed \& Ali, 2010).

\subsection{Employee engagement (ENG)}

Employee engagement is an appointment that offers employees the opportunity to influence managerial decision-making at a certain level through the exchange of knowledge and experiences (Rich et al., 2010). In Islam, it promotes employees to be proactive in strategy formulation or planning and empowers their willingness to pursue an organizational vision continuously and constructively (Rana \& Malik, 2016). Margaretha et al. (2021) analyzed the effect of employee engagement on organizational commitment. The study used data obtained from 322 lecturers who are employed in various universities in Indonesia. It was shown that there is a significant relationship between these 2 constructs, supporting Saks (2006) and Salanova et al. (2005). In contrast, Rameshkumar (2020) reported that employee engagement barely affects organizational commitment in India. In addition, regarding its influence on in-role performance, Anitha (2014), Hamid and Ashoer (2021), and Kim et al. (2013) confirmed that employee engagement positively and significantly affects employee performance.

\subsection{Job satisfaction (JS)}

Job satisfaction is perceived as a way to motivate proper human behavior in organizations (Malik, 2018). According to Spector (1997), job satisfaction is one's emotions concerning various aspects of the job. Conversely, DeCenzo et al. (2015) stated that it occurs when people feel they deserve to be recognized because of their skills and values. Giri and Pavan Kumar (2010) reported it as the main driver of supportive attitudes and behavior in an organization that portrays the employees' perspective of work. In Indonesia, Hayati and Caniago (2012) studied 149 Islamic bank employees and discovered a positive relationship between job satisfaction and organizational commitment. Likewise, Bakotić (2016), Eliyana et al. (2019), and Gheitani et al. (2019) reported a similar occurrence. Furthermore, the influence of job satisfaction on in-role performance was investigated by Al-Douri et al. (2020) and Özpehlivan et al. (2016), confirming that it positively affects job performance.

\subsection{Organizational commitment (OC)}

The notion of commitment refers to the preference of social activists to exude their vitality in terms of expressing loyalty or emotional attachment to the system or organization, regardless of the utility value of these relationships (Lindawati \& Wulani, 2021). Zeuch (2016) described it as personal ownership and dependence on an organization, or loyalty to organizational goals recognizing and accepting its values. Therefore, through organizational commitment, employees perceive the organization as its representative and desire to join. Yousef (2001), Nasution and Rafiki (2020), and Miswanto et al. (2020) examined the impact of organizational commitment on performance and reported that organizational commitment significantly affects job performance. Conversely, Eliyana et al. (2019) stated that it has an insignificant influence on performance.

\subsection{Mediation role of ENG, JS, and OC}

Islamic values are an important element of a personality; therefore, organizations can motivate people to perform better using such values (Wahab \& Masron, 2020). The process of self-actualization of pure Islam requires a proportional social growth (maslaha ammah) via self-correction (tazkiyatu nafs) (Mellahi \& Budhwar, 2010). As a result, employees who possess high spirituality and work ethic and receive support from their employers are resistant to challenges and possess good attitudes. However, through literature review and demonstration of the relationship between various variables, it was discovered that employee engagement, job satisfaction, and organizational commitment play a mediating function (Athar et al., 2016; Margaretha et al., 2021; Rawwas et al., 2018; Yousef, 2000). To enrich theories as suggested by Khan et al. (2010), it is interesting to examine whether they can mediate the relationship between IWV and in-role performance. 


\section{AIMS AND HYPOTHESES}

Following the literature review, this study aims to investigate the influence of IWV on employee engagement, job satisfaction, organizational commitment, and in-role performance of Muslim employees in Indonesia. Subsequently, to provide novel findings, it also analyzed the potential mediation effect of employee engagement, job satisfaction, and organizational commitment on the direct relationship between IWV and in-role performance. The proposed conceptual framework is portrayed in Figure 1.

The study thus proposes the following hypotheses:

H1: IWV has a significant influence on employee engagement.

H2: IWV has a significant influence on job satisfaction.

H3: IWV has a significant influence on organizational commitment.

H4: IWV has a significant influence on in-role performance.

H5: Employee engagement has a significant influence on organizational commitment.
H6: Employee engagement has a significant influence on in-role performance.

H7: Job satisfaction has a significant influence on organizational commitment.

H8: Job satisfaction has a significant influence on in-role performance.

H9: Organizational commitment has a signifcant influence on in-role performance.

H10a: Employee engagement mediates the relationship between IWV and in-role performance.

H10b: Job satisfaction mediates the relationship between IWV and in-role performance.

H10c: Organizational commitment mediates the relationship between $I W V$ and in-role performance.

\section{METHODOLOGY}

\subsection{Sampling and data collection}

This study focuses on all Muslim employees in Makassar city, Indonesia, which is a secular constitution and institutional framework. Due to the excessively large number, purposive sampling, which

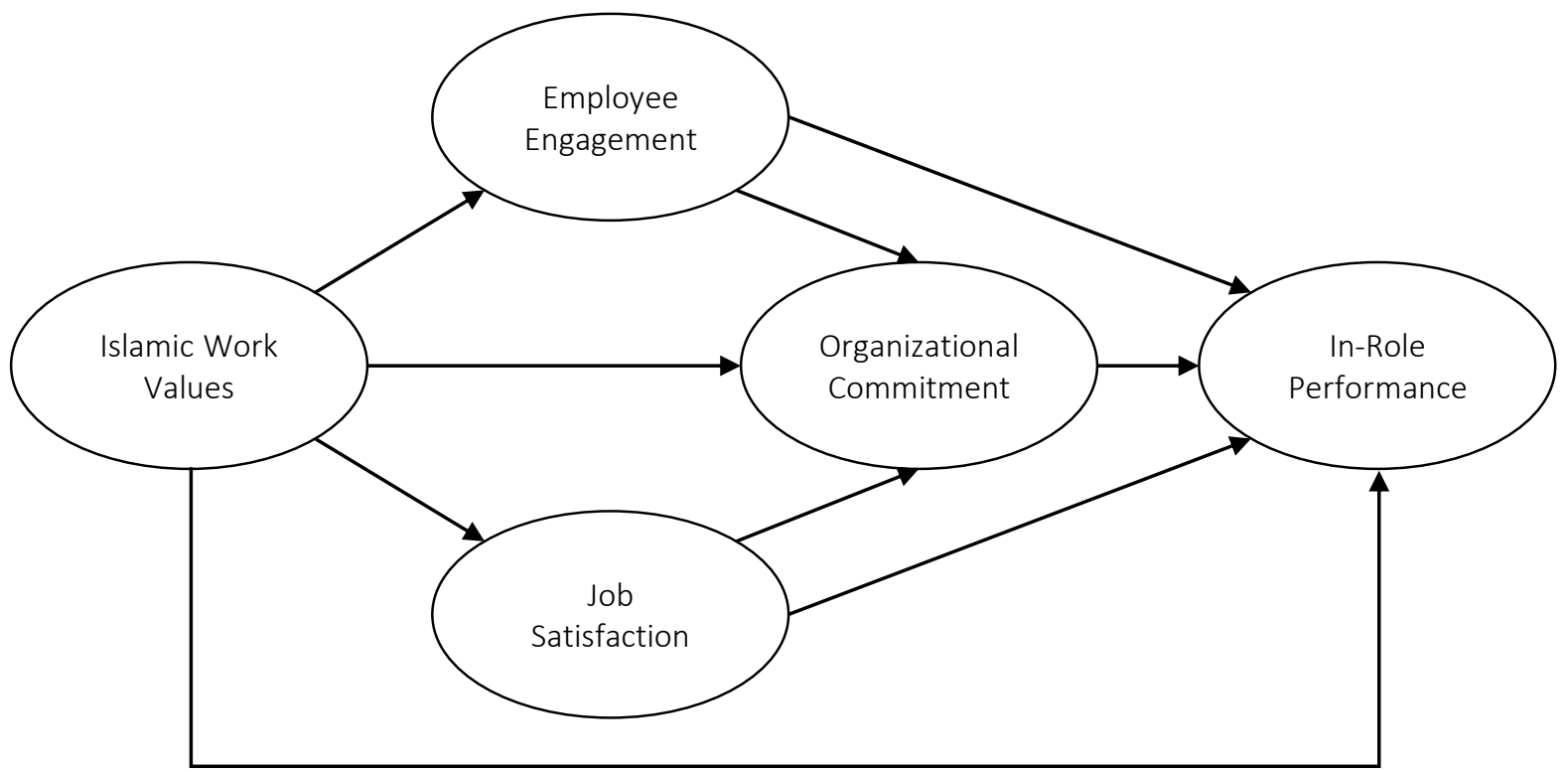

Figure 1. Conceptual framework model 
was considered the most appropriate technique, was adopted (Sreejesh et al., 2014). In more detail, the purposive homogeneous sample was preferred because the respondents had similar characteristics, namely, they were all Muslim employees. Accurate results were obtained based on several criteria such as (1) permanent employees (not contract), (2) having at least 3 years of work experience, (3) have not changed the place of work. Therefore, these criteria are crucial to obtain a sample following the problems that need to be resolved in this study.

The study used an online questionnaire; it was adopted to minimize the spread of the COVID-19 pandemic. Another technical reason was to provide broad access to the respondents in Makassar city at an affordable cost, ease of use, and time efficiency (Evans \& Mathur, 2005). An online questionnaire using Google Forms was provided and distributed through emails and social media, such as WhatsApp and Facebook. The primary data were collected during 2 months (JanuaryFebruary 2021); 329 responses were obtained and put in the e-form database. However, 46 of them were denied during the validation procedure due to the failure to meet the stipulated sampling requirements, filling out the profile data, and e-questionnaire haphazardly. Consequently, 283 responses were obtained. The possible justification behind this high rate was the use of an online questionnaire as an alternative to help respondents in filling out the forms at home.

\subsection{Data analysis}

The study adopted a PLS-SEM analysis technique. In social science studies, SEM is used to create the measurements of an idea or aspect that is typically employed and calculate its impact empirically (Rigdon et al., 2017). Furthermore, this instrument is also used to test the mediating influence between the variables. Its analysis is divided into 2 parts, namely measurement and structural models (Shmueli et al., 2019). The measurement model checks the validity and reliability of data analyzed, as well as assesses the significance between variables.

\subsection{Construct measurement}

This study measured 5 constructs, and the questionnaire that covered IWV was adapted from the qualitative study carried out by Wahab and Masron (2020), which consisted of 8 items. These 2 constructs were measured with 3 items, where the items of employee engagement were adapted from Kumar and Sia (2012) and Rich et al. (2010) while the items of job satisfaction were obtained from Yousef (2001). Items for organizational commitment and in-role performance were adapted from Gheitani et al. (2019), and Kim et al. (2019) consisted of 4 and 5 items, respectively. All of the items were ranked on a 5-point Likert scale, from 1 ("strongly disagree") to 5 ("strongly agree").

\section{RESULTS}

\subsection{Respondents}

Table 1. Demographics $(N=283)$

\begin{tabular}{|c|c|c|}
\hline Characteristics & Frequency & Percentage \\
\hline \multicolumn{3}{|c|}{ Gender } \\
\hline Male & 110 & $38.9 \%$ \\
\hline Female & 173 & $61.1 \%$ \\
\hline \multicolumn{3}{|c|}{ Age } \\
\hline$<30$ years old & 95 & $33.6 \%$ \\
\hline $30-40$ years old & 108 & $38.2 \%$ \\
\hline $40-50$ years old & 57 & $20.1 \%$ \\
\hline$>50$ years old & 23 & $8.1 \%$ \\
\hline \multicolumn{3}{|c|}{ Education level } \\
\hline High School & 74 & $26.1 \%$ \\
\hline Bachelor (or D4) & 191 & $67.5 \%$ \\
\hline Magister & 18 & $6.4 \%$ \\
\hline \multicolumn{3}{|c|}{ Work experience } \\
\hline$\leq 5$ years & 109 & $38.5 \%$ \\
\hline$>5$ years & 174 & $61.5 \%$ \\
\hline \multicolumn{3}{|c|}{ Business service sector } \\
\hline Financial services & 107 & $37.8 \%$ \\
\hline $\begin{array}{l}\text { Tourism, hospitality, and } \\
\text { leisure }\end{array}$ & 80 & $28.3 \%$ \\
\hline ITC and sharing economy & 35 & $12.4 \%$ \\
\hline Retail & 44 & $15.5 \%$ \\
\hline Others & 17 & $6.0 \%$ \\
\hline
\end{tabular}

Based on gender, the majority (61.1\%) were females aged 35 to 45 years. Viewing education, $67.5 \%$ had a Bachelor's degree. Moreover, 61.5 \% have been working for more than 5 years. According to the service sectors, financial institutes had the biggest portion of approximately $37.8 \%$, followed by tourism, hospitality, and leisure, ITC and sharing economy, retail, etc. Regarding employee in-role performance, the respondents' demographics are perceived as essential for stakeholders as a basis for decision-making. 


\subsection{Measurement or outer model assessment}

The study assessed the research model testing the indicator loadings and values greater than 0.708 were recommended (Hair et al., 2019). Based on the results, all measurement items have a value greater than 0.7. Therefore, they were declared valid and reliable in terms of measuring the variables. Next, the paper assessed the reliability of internal consistency by referring to the Composite Reliability (CR) and Cronbach's alpha (CA), where higher values normally mean absolute reliability. For instance, a value between 0.60 and 0.70 is regarded as "acceptable in the exploratory study", while those between 0.70 and 0.90 are "satisfactory to good" (Rigdon et al., 2017). According to the results, all variables had CR and CA values greater than 0.7. Therefore, they were assumed to fulfill the relia- bility requirements. The third step involves testing the convergent validity of each construct measure, and the study used Average Variance Extracted (AVE) for all items. A satisfactory AVE of 0.50 or higher shows that a construct defines a minimum of $50 \%$ of the item variance. Based on the output, all values acquired were greater than 0.5 , therefore the AVE was confirmed. The paper also assessed discriminant validity, namely the degree to which a construct empirically differs from others. It was based on 2 criteria, namely Fornell-Larcker and cross-loadings. In Fornell-Larcker, the AVE square root is compared with the correlation of the latent variables. According to the results, AVE roots for all constructs and the loading factors of all measurement items were more significant compared to the quadratic correlation with the other variables. Therefore, the discriminant valid criteria were fulfilled.

Table 2. Outer model assessment

\begin{tabular}{|c|c|c|c|c|c|}
\hline $\begin{array}{l}\text { Latent } \\
\text { constructs }\end{array}$ & Items & $\begin{array}{l}\text { Factor } \\
\text { loadings }\end{array}$ & AVE & C.R. & C.A. \\
\hline \multirow{8}{*}{$\begin{array}{l}\text { Islamic Work } \\
\text { Values (IWV) }\end{array}$} & IWV1 - Piety (taqwa) & 0.708 & \multirow{8}{*}{0.542} & \multirow{8}{*}{0.904} & \multirow{8}{*}{0.879} \\
\hline & IWV2 - Trustworthiness (Amanah) & 0.773 & & & \\
\hline & IWV3 - Truthfulness (sidq) & 0.710 & & & \\
\hline & IWV4 - Benevolence (ihsan) & 0.759 & & & \\
\hline & IWV5 - Sincerity (ikhlas) & 0.758 & & & \\
\hline & IWV6 - Timeliness (iltizam bil mawa'id) & 0.791 & & & \\
\hline & IWV7 - Hardworking (mujahadah) & 0.783 & & & \\
\hline & IWV8 - Patience (sabr) & 0,703 & & & \\
\hline \multirow{3}{*}{$\begin{array}{l}\text { Employee } \\
\text { Engagement } \\
\text { (ENG) }\end{array}$} & ENG1 - They focus on their job intensively & 0.815 & \multirow{3}{*}{0.619} & \multirow{3}{*}{0.829} & \multirow{3}{*}{0.791} \\
\hline & ENG2 - They undertake a huge effort to complete their work & 0.728 & & & \\
\hline & ENG3 - They attempt to complete their work properly & 0.814 & & & \\
\hline \multirow{3}{*}{$\begin{array}{l}\text { Job } \\
\text { Satisfaction } \\
\text { (JS) }\end{array}$} & JS1 - They feel the salary is as per the applicable regulations & 0.815 & \multirow{3}{*}{0.712} & \multirow{3}{*}{0.881} & \multirow{3}{*}{0.797} \\
\hline & JS2 - They agree with the criteria used in the promotion & 0.854 & & & \\
\hline & JS3 - They enjoy working with responsible partners & 0.861 & & & \\
\hline \multirow{4}{*}{$\begin{array}{l}\text { Organizational } \\
\text { Commitment } \\
\text { (OC) }\end{array}$} & OC1 - They feel that this organization is the best place to work & 0.729 & \multirow{4}{*}{0.601} & \multirow{4}{*}{0.857} & \multirow{4}{*}{0.778} \\
\hline & OC2 - They proudly tell others that they are part of this organization & 0.829 & & & \\
\hline & OC3 - They are willing to do a lot of work & 0.762 & & & \\
\hline & $\begin{array}{l}\text { OC4 - They complete tasks beyond the main task for the improvement of the } \\
\text { organization }\end{array}$ & 0.777 & & & \\
\hline \multirow{5}{*}{$\begin{array}{l}\text { In-Role } \\
\text { Performance } \\
\text { (IRP) }\end{array}$} & IRP1 - They finalize the appointed tasks sufficiently & 0.774 & \multirow{5}{*}{0.579} & \multirow{5}{*}{0.818} & \multirow{5}{*}{0.873} \\
\hline & IRP2 - They comply with structured job output criteria & 0.769 & & & \\
\hline & IRP3 - They neglect some tasks they have to execute & 0.770 & & & \\
\hline & IRP4 - They execute the tasks assigned to them & 0.771 & & & \\
\hline & IRP5 - They regularly carry out high performing job tasks & 0.718 & & & \\
\hline
\end{tabular}

Note: AVE: Average Variance Extracted; CR: Composite Reliability; CA: Cronbach's alpha. PLS Valid and Reliable Cut-off value: AVE > 0.5; Factor Loadings, CR and CA $>0.7$. 
Table 3. Discriminant validity evaluation with Fornell-Larcker criterion

\begin{tabular}{|c|c|c|c|c|c|c|}
\hline Constructs & IWV & ENG & JS & OC & IRP & VIF \\
\hline Islamic Work Values (IWV) & $(0.736)$ & & & & & 2.192 \\
\hline Employee Engagement (ENG) & 0.624 & $(0.787)$ & & & & 2.233 \\
\hline Job Satisfaction (JS) & 0.601 & 0.627 & $(0.844)$ & & & 2.066 \\
\hline Organizational Commitment & 0.683 & 0.525 & 0.629 & $(0.775)$ & & 2.221 \\
\hline In-Role Performance (IRP) & 0.518 & 0.539 & 0.640 & 0.633 & $(0.785)$ & 1.995 \\
\hline
\end{tabular}

Note: Square roots of Average Variances Extracted (AVEs) are shown diagonally (in bold), VIF indicates Variance Inflation Factor.

Table 4. Cross loadings

\begin{tabular}{|c|c|c|c|c|c|}
\hline $\begin{array}{l}\text { Constructs/ } \\
\text { Items }\end{array}$ & Islamic Work Values & Engagement & Job Satisfaction & $\begin{array}{c}\text { Organizational } \\
\text { Commitment }\end{array}$ & In-role Performance \\
\hline IWV1 & 0.708 & 0.497 & 0.510 & 0.402 & 0.534 \\
\hline IWV2 & 0.773 & 0.626 & 0.531 & 0.555 & 0.632 \\
\hline IWV3 & 0.710 & 0.469 & 0.454 & 0.429 & 0.596 \\
\hline IWV4 & 0.759 & 0.516 & 0.424 & 0.616 & 0.604 \\
\hline IWV5 & 0.758 & 0.531 & 0.538 & 0.601 & 0.690 \\
\hline IWV6 & 0.791 & 0.682 & 0.572 & 0.672 & 0.629 \\
\hline IWV7 & 0.783 & 0.604 & 0.485 & 0.602 & 0.531 \\
\hline IWV8 & 0,703 & 0.527 & 0.596 & 0.335 & 0.599 \\
\hline ENG1 & 0.548 & 0.815 & 0.600 & 0.339 & 0.655 \\
\hline ENG2 & 0.588 & 0.728 & 0.544 & 0.676 & 0.512 \\
\hline ENG3 & 0.577 & 0.814 & 0.664 & 0.671 & 0.666 \\
\hline JS1 & 0.543 & 0.515 & 0.815 & 0.503 & 0.630 \\
\hline JS2 & 0.511 & 0.683 & 0.854 & 0.609 & 0.595 \\
\hline JS3 & 0.567 & 0.645 & 0.861 & 0.650 & 0.719 \\
\hline OC1 & 0.663 & 0.533 & 0.433 & 0.729 & 0.563 \\
\hline $\mathrm{OC2}$ & 0.527 & 0.623 & 0.407 & 0.829 & 0.620 \\
\hline OC3 & 0.688 & 0.558 & 0.300 & 0.762 & 0.641 \\
\hline OC4 & 0.595 & 0.677 & 0.399 & 0.777 & 0.495 \\
\hline IRP1 & 0.643 & 0.541 & 0.520 & 0.440 & 0.774 \\
\hline IRP2 & 0.417 & 0.578 & 0.546 & 0.591 & 0.769 \\
\hline IRP3 & 0.705 & 0.572 & 0.494 & 0.584 & 0.770 \\
\hline IRP4 & 0.490 & 0.629 & 0.706 & 0.414 & 0.771 \\
\hline IRP5 & 0.481 & 0.626 & 0.732 & 0.410 & 0.718 \\
\hline
\end{tabular}

Note: Bold values are loadings for the items above the recommended value of 0.7 .

\subsection{Inner model assessment}

Before assessing the model with the PLS-SEM, Variance Inflation Factors (VIF) were checked to avoid collinearity. Ideally, it has to be close to 3 or lesser. Meanwhile, a value of 5 or greater is considered to possess critical collinearity between the construct indicators (Chin, 2010). Based on Table 3, all VIF values in each construct were less than 3 , indicating no multicollinearity problem. Furthermore, the evaluation of the model was carried out by analyzing the $R$-Square $\left(R^{2}\right)$ for each endogenous latent variable, which is regarded as the predictive power. The results showed that the
$R^{2}$ values for each of the 4 endogenous variables (ENG, JS, OC, and IRP) were 0.442 (44.2\%), 0.470 (47\%), 0.541 (54.1\%), and 0.579 (57.9\%), respectively. This shows that $R^{2}$ exceeded the recommended threshold, indicating a moderate (fit) model (Hair et al., 2019). The PLS-SEM-based hypothesis testing was taken by performing a bootstrapping process using the smartPLS 3.0 program to determine the impact of exogenous variables on endogenous. The cut-off of the $t$-table was 1.99, acquaired from the alpha level of $95 \%$ and the degrees of freedom (df) $=n-2 ; 283-2=281$. The hypothesis testing for each latent variable relationship is shown in Figure 2. 


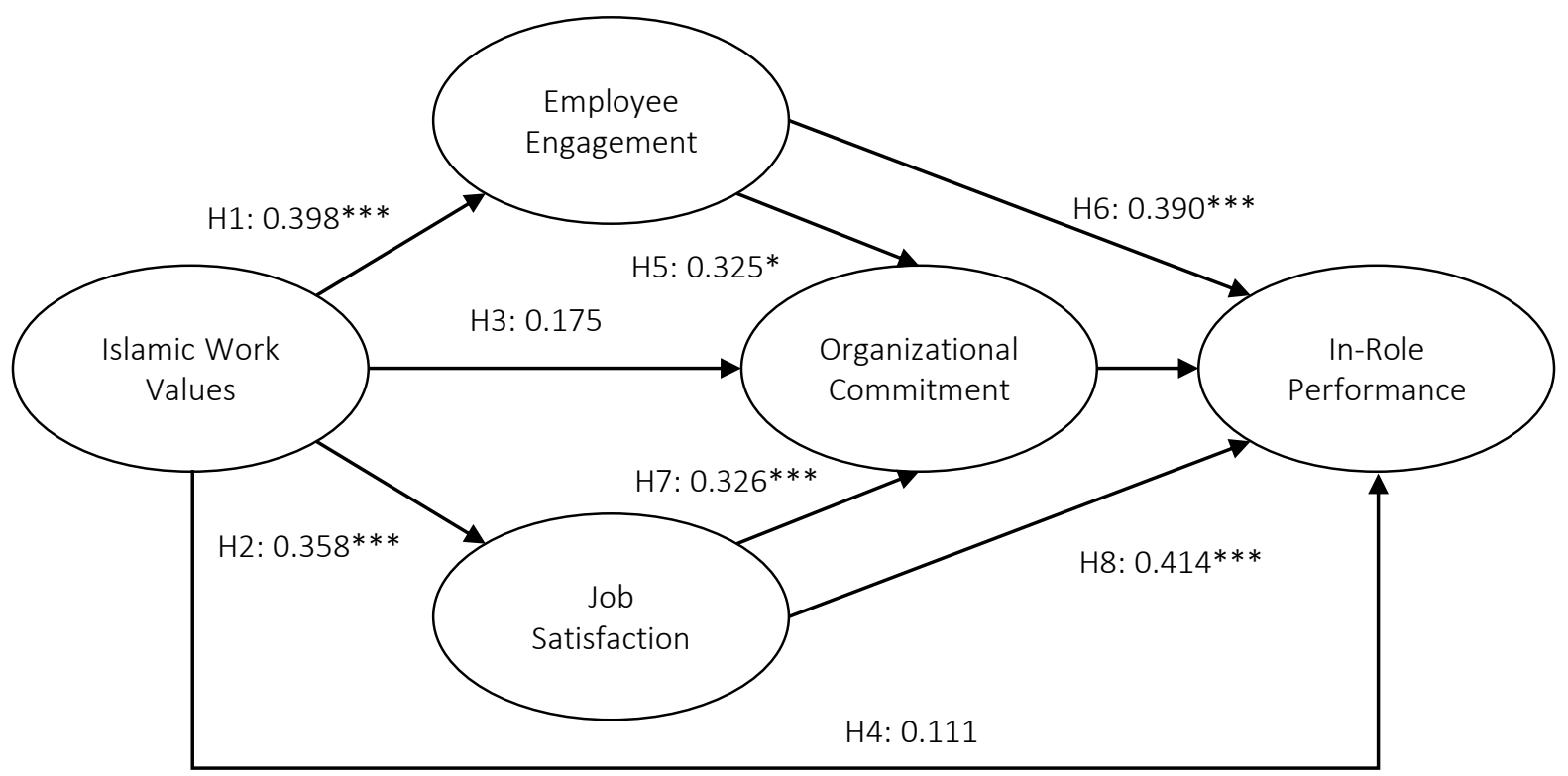

Note: standardized coefficients are reported. ${ }^{*} p<0.05,{ }^{* * *} p<0.001$.

Figure 2. PLS-SEM analysis result

$H 1, H 2, H 3$, and $H 4$ were used to predict the influence of IWV on 4 dependent constructs. The analysis shows that it significantly influences ENG ( $\beta$ $=0.398, t$-value $=4.189, p<0.000)$, JS $(\beta=0.358$, $t$-value $=3.691, p<0.000)$, and OC $(\beta=0.175$, $t$-value $=1.326, p<0.186)$, as well as insignificantly affects IRP $(\beta=0.111, t$-value $=0.933, p<0.352)$. Therefore, $H 1, H 2$, and $H 3$ were supported and $H 4$ was rejected. Furthermore, $H 5$ and $H 6$ postulated the associations between ENG and the 2 dependent variables. The findings showed that ENG has a significant and positive effect on OC $(\beta=0.325$, $t$-value $=2.708, p<0.007)$, and IRP $(\beta=0.390$, $t$-value $=3.786, p<0.000)$, which supports $H 5$ and H6. Subsequently, $H 7$ and $H 8$ predicted the influence of JS on 2 dependent constructs, where the output revealed that it has a significant effect on OC $(\beta=0.326, t$-value $=3.747, p<0.000)$, and IRP $(\beta=0.414, t$-value $=4.313, p<0.000)$, thereby $H 7$ and $\mathrm{H} 8$ are confirmed. Moreover, $\mathrm{H} 9$ investigated the influence between OC and IRP, resulting in a significant effect $(\beta=0.375, t$-value $=4.167$, $p<0.000)$. Therefore, $H 9$ was confirmed. Finally, $\mathrm{H} 10 \mathrm{a}, \mathrm{H1Ob}$, and $\mathrm{H} 1 \mathrm{Cc}$ analyzed the indirect influence on the relationship between IWV and IRP. The output showed that 3 mediators namely ENG

Table 5. Hypotheses testing

\begin{tabular}{|c|c|c|c|c|c|c|}
\hline $\mathbf{H}$ & Direct Effect & $\beta$ & Std. Error & $T$-value & $P$-value & Decision \\
\hline$H 1$ & $I W V \rightarrow E N G$ & 0.398 & 0.095 & 4.189 & 0.000 & Supported \\
\hline $\mathrm{H} 2$ & IWV $\rightarrow$ JS & 0.358 & 0.097 & 3.691 & 0.000 & Supported \\
\hline $\mathrm{H3}$ & $I W V \rightarrow O C$ & 0.175 & 0.132 & 1.326 & 0.186 & Rejected \\
\hline $\mathrm{H4}$ & $I W V \rightarrow I R P$ & 0.111 & 0.119 & 0.933 & 0.352 & Rejected \\
\hline H5 & ENG $\rightarrow O C$ & 0.325 & 0.120 & 2.708 & 0.007 & Supported \\
\hline H6 & $E N G \rightarrow I R P$ & 0.390 & 0.103 & 3.786 & 0.000 & Supported \\
\hline$H 7$ & $\mathrm{IS} \rightarrow \mathrm{OC}$ & 0.326 & 0.087 & 3.747 & 0.000 & Supported \\
\hline H8 & $\mathrm{JS} \rightarrow \mathrm{IRP}$ & 0.414 & 0.096 & 4.313 & 0.000 & Supported \\
\hline $\mathrm{H} 9$ & $\mathrm{OC} \rightarrow \mathrm{IRP}$ & 0.375 & 0.092 & 4.167 & 0.000 & Supported \\
\hline $\mathbf{H}$ & Mediation Effect & $\beta$ & Std. Error & $T$-value & $P$-value & Decision \\
\hline $\mathrm{H} 1 \mathrm{Oa}$ & $\mathrm{IWV} \rightarrow \mathrm{ENG} \rightarrow \mathrm{IRP}$ & 0.250 & 0.101 & 2.475 & 0.014 & Supported \\
\hline $\mathrm{H} 1 \mathrm{Ob}$ & $I W V \rightarrow J S \rightarrow I R P$ & 0.219 & 0.107 & 2.047 & 0.042 & Supported \\
\hline $\mathrm{H} 1 \mathrm{OC}$ & $\mathrm{IWV} \rightarrow \mathrm{OC} \rightarrow \mathrm{IRP}$ & 0.248 & 0.091 & 2.756 & 0.006 & Supported \\
\hline
\end{tabular}

Note: IWV = Islamic Work Values; ENG = Engagement; JS = Job Satisfaction; OC = Organizational Commitment; IRP = In-Role Performance Significance: $P$-value $<0.05$ and $T$-value $>1.98$. 
$(\beta=0.250, t$-value $=2.475, p<0.014), \mathrm{JS}(\beta=0.219$, $t$-value $=2.047, p<0.042)$, and OC $(\beta=0.248$, $t$-value $=2.756, p<0.006)$ fully mediates the main effect, therefore, $\mathrm{H} 10 \mathrm{a}, \mathrm{H1Ob}$, and $\mathrm{H} 10 \mathrm{c}$ were supported. The outcomes of the hypothesized relationships testing the direct and indirect influence are summarized in Table 5.

\section{DISCUSSION}

The outcomes obtained explain the different influences of IWV, which was mediated by several constructs, and its justification rests on the Muslim employees' background in Makassar city. First, its significant influence on ENG and JS is supported by Gheitani et al. (2019) and Yousef (2001). These positive results indicate that supporters of Islamic work ethics are more determined and pleased with their work. However, values such as mujahadah (hardworking) cause them to be responsible and develop trust. Another teaching is sidq (truthfulness), where employees strive to optimize resources in realizing a positive influence on themselves and organizations. In addition, these positive attitudes offer several benefits, e.g. hardworking, loyalty, devotion, creativeness, partnership, and unbiased competitiveness in the workplace. They are maintained by developing human resource programs in line with Islamic values without having to sacrifice the company's main vision and mission.

In contrast to previous studies, the influence of IWV on OC and IRP is insignificant. This is because there is no harmony between the Islamic values adopted by employees and the organizational vision or mission, even though Muslims are highly committed to their jobs. Another reason is the background of the respondents' companies, which are divided into several sectors such as banking or technology (ICT), which have not been considered crucial and do not need to be brought to the surface. Moreover, this is certainly problematic because it influences the achievement of employees' core performances. Therefore, minimizing the negative influence was carried out through engagement. Employees who keep work ethics tend to be more loyal to their organizations because in Islam this attribute is a virtue.

Another significant relationship was found in the effect of ENG on OC and IRP, which is conclusively in line with Miswanto et al. (2020), Kim et al. (2019), and Kumar and Sia (2012). Engagement is important for any organization looking to retain valuable employees, particularly in the context of Islamic HR. A company's ability to manage ENG is closely related to its ability to achieve high performance and superior results. Furthermore, the JS construct significantly influences OC and IRP and confirms the results of Asutay et al. (2021) and Sinaulan et al. (2017). Ensuring employee satisfaction is one of the most important duties of organizational management. Furthermore, the significant relationship between OC and IRP is also in line with preliminary studies carried out by Eliyana et al. (2019) and Hayati and Caniago (2012). Accordingly, loyal employees execute their core performance in the company and increase their concern for organizational success and development.

Finally, it was discovered that the 3 moderator variables (ENG, JS, and OC) perfectly mediate the insignificant relationship between IWV and IRP. These results indicate that the completion of the main duties or work responsibilities carried out by employees is highly dependent on employee engagement, satisfaction, and organizational commitment.

\section{CONCLUSION}

The study proved that IWV directly has a positive and significant impact on employee engagement and job satisfaction. Conversely, it has an insignificant effect on organizational commitment and in-role performance. Furthermore, the results showed a significant relationship between 4 endogenous variables, namely employee engagement, job satisfaction, organizational commitment, and in-role performance. Finally, employee engagement, job satisfaction, and organizational commitment significantly mediate the relationship between IWV and in-role performance. Based on the results, this study has 
some practical implications that need to be adopted by the company's management to improve their employees' in-role performance through Islamic values. First, the findings confirmed that IWV significantly affects employee engagement and job satisfaction; this benefits managers because attributes such as honesty or hard work certainly influence organizational climate positively. Considering the insignificant relationship between IWV and in-role performance, the company needs to create more roles and opportunities for employees to actualize their dreams, both individually and organizationally. In addition, policymakers and experts are also permitted to use these findings to support IWV, which as the main instrument is highly respected. Islamic organizations, in particular, need to help companies reduce ideological clashes between individuals and companies, which often have a negative influence on employee productivity. Managers are expected to introduce Islamic values and work directions through training programs to increase IWE levels among employees. Therefore, their core performance is expected to be high as studies across many major management streams discovered that employee values are aligned with that of the organization.

Although this study adhered to scientific principles and rules, its results and implications are still figurative and need to be viewed with due regard to the subsequent boundaries. Foremost, these conclusions are difficult to generalize because they contain only one general characteristic that is relatively similar to Islam and Muslim employees. Future studies are expected to broaden the respondents' demographics by involving other regions and countries to investigate this topic further. Second, the established direct relationship between IWE and in-role performance is insignificant, which tends to encourage future studies to analyze this issue. Third, further studies need to reuse or develop the IWV core items to obtain accurate results from various points of view. Finally, given the limitations in this theoretical model, future studies need to consider mediators or moderators that are popular and relevant to the current pandemic conditions, such as attitudes or knowledge about COVID-19 and work from home behavior.

\section{AUTHOR CONTRIBUTIONS}

Conceptualization: Munawir Nasir Hamzah, Nasir Hamzah.

Data curation: Munawir Nasir Hamzah, Muhammad Ashoer.

Formal analysis: Munawir Nasir Hamzah, Muhammad Ashoer.

Funding acquisition: Munawir Nasir Hamzah.

Investigation: Munawir Nasir Hamzah, Muhammad Ashoer.

Methodology: Muhammad Ashoer.

Project administration: Munawir Nasir Hamzah.

Resources: Munawir Nasir Hamzah.

Software: Muhammad Ashoer.

Supervision: Munawir Nasir Hamzah, Nasir Hamzah.

Validation: Muhammad Ashoer.

Visualization: Muhammad Ashoer.

Writing - original draft: Munawir Nasir Hamzah, Muhammad Ashoer.

Writing - review \& editing: Munawir Nasir Hamzah, Nasir Hamzah.

\section{REFERENCES}

1. Al-Douri, J. A., Aldabbagh, I., Mohammad, M. M., \& Qawasmeh, R. (2020). The impact of islamic work ethics on job performance with mediating role of intrinsic motivation. Academy of Strategic Management Journal, 19(2), 1939-6104. Retrieved from https://www.abacademies.
org/articles/The-impact-of-islamic-

work-ethics-on-job-performancewith-mediating-role-of-intrinsicmotivation-1939-6104-19-1-525.pdf

2. Ali, A. J. (2010). Islamic Challenges to HR in Modern Organizations. Personnel Review,
39(6), 692-711. https://doi. org/10.1108/00483481011075567

3. Ali, A. J., \& Al-Owaihan, A. (2008). Islamic work ethic: a critical review. Cross Cultural Management: An International Journal, 15(1), 5-19. https://doi. org/10.1108/13527600810848791 
4. Al-Shamali, A., Irani, Z., Haffar, M., Al-Shamali, S., \& Al-Shamali, F. (2021). The influence of Islamic Work Ethic on employees' responses to change in Kuwaiti Islamic banks. International Business Review, 30(5), 101817. https://doi.org/10.1016/j. ibusrev.2021.101817

5. Anitha, J. (2014). Determinants of employee engagement and their impact on employee performance. International Journal of Productivity and Performance Management, 63(3), 308-323. https://doi. org/10.1108/IJPPM-01-2013-0008

6. Asutay, M., Buana, G. K., \& Avdukic, A. (2021). The Impact of Islamic Spirituality on Job Satisfaction and Organisational Commitment: Exploring Mediation and Moderation Impact. Journal of Business Ethics, 1, 1-20. https://doi.org/10.1007/ S10551-021-04940-Y

7. Athar, M. R., Shahzad, K., Ahmad, J., \& Ijaz, M. S. (2016). Impact of Islamic work ethics on organizational commitment: Mediating role of job satisfaction. Journal of Islamic Business and Management, 6(1), 119-134. Retrieved from https://jibm.org/ wp-content/uploads/2018/05/9_Razzaq-Athar-Et-al-Impact-ofIslamic-Work-Ethics-26-7-16.pdf

8. Bakotić, D. (2016). Relationship between job satisfaction and organisational performance. Economic Research-Ekonomska Istrazivanja, 29(1), 118-130. https://doi.org/10.10 80/1331677X.2016.1163946

9. Chin, W. W. (2010). How to Write Up and Report PLS Analyses. In V. Esposito Vinzi, W. Chin, J. Henseler, \& H. Wang (Eds.), Handbook of Partial Least Squares (pp. 655-690). Springer, Berlin, Heidelberg. https:// doi.org/10.1007/978-3-540-328278_29

10. Chowdhury, A. H., Hoque, N., \& Mawla, M. M. (2012). Human Resource Management from Islamic Perspective. Bangladesh Journal of Islamic Thought, 7(10), 19-36.

11. DeCenzo, D. A., Robbins, S. P., \& Verhulst, S. L. (2015). Fundamentals of Human Resource Management $\left(12^{\text {th }}\right.$ ed.). Wiley. Retrieved from https://www.wiley.com/en-us/Fun damentals+of + Human + Resource+ Management $\% 2 \mathrm{C}+12$ th+Editionp-9781119158905
12. Eliyana, A., Mảarif, S., \& Muzakki. (2019). Job satisfaction and organizational commitment effect in the transformational leadership towards employee performance. European Research on Management and Business Economics, 25(3), 144-150. https://doi.org/10.1016/J. IEDEEN.2019.05.001

13. Evans, J. R., \& Mathur, A. (2005). The value of online surveys. Internet Research, 15(2), 195-219. https://doi. org/10.1108/10662240510590360

14. Farid, T., Iqbal, S., Jianhong, M., Mushtaq, T., \& Mehmood, Q. (2017). Effect of islamic work ethics on employees work engagement and organizational citizenship behavior. Psychologia, 60(3), 111-120. https:// doi.org/10.2117/PSYSOC.2018-001

15. Gheitani, A., Imani, S., Seyyedamiri, N., \& Foroudi, P. (2019). Mediating effect of intrinsic motivation on the relationship between Islamic work ethic, job satisfaction, and organizational commitment in banking sector. International Journal of Islamic and Middle Eastern Finance and Management, 12(1), 76-95. https://doi.org/10.1108/ IMEFM-01-2018-0029

16. Giri, V. N., \& Pavan Kumar, B. (2010). Assessing the impact of organizational communication on job satisfaction and job performance. Psychological Studies, 55(2), 137-143. https://doi.org/10.1007/s12646-0100013-6

17. Hair, J. F., Risher, J. J., Sarstedt, M., \& Ringle, C. M. (2019). When to use and how to report the results of PLS-SEM. European Business Review, 31(1), 2-24. https://doi.org/10.1108/ EBR-11-2018-0203

18. Hamid, H., \& Ashoer, M. (2021). Determinant and Consequence of Civil Servant Engagement: A Mediated-Moderated Study. Jurnal Manajemen, 25(1), 20-38. https:// doi.org/10.24912/jm.v25i1.701

19. Hayati, K., \& Caniago, I. (2012). Islamic Work Ethic: The Role of Intrinsic Motivation, Job Satisfaction, Organizational Commitment and Job Performance. Procedia - Social and Behavioral Sciences, 65 , 272-277. https://doi.org/10.1016/J. SBSPRO.2012.11.122
20. Khan, B., Farooq, A., \& Hussain, Z. (2010). Human resource management: an Islamic perspective. AsiaPacific Journal of Business Administration, 2(1), 17-34. https://doi. org/10.1108/17574321011037558

21. Kim, W., Han, S. J., \& Park, J. (2019). Is the Role of Work Engagement Essential to Employee Performance or 'Nice to Have'? Sustainability, 11(4), 1050. https://doi.org/10.3390/ su11041050

22. Kim, W., Kolb, J. A., \& Kim, T. (2013). The Relationship Between Work Engagement and Performance: A Review of Empirical Literature and a Proposed Research Agenda. Human Resource Development Review, 12(3), 248-276. https:// doi.org/10.1177/1534484312461635

23. Kumar, R., \& Sia, S. K. (2012). Employee Engagement: Explicating the Contribution of Work Environment. Management and Labour Studies, 37(1), 31-43. https://doi.org /10.1177/0258042X1103700104

24. Lindawati, T., \& Wulani, F. (2021). The Commitment of the Employee to the Supervisor and the Organization: The Role of Employee Competency and Downward Influence Tactics. Asian Journal of Business Research, 11(1). https://doi. org/10.14707/AJBR.210096

25. Malik, A. (2018). Strategic Human Resource Management and Employment Relations. Singapore: Springer. https://doi.org/10.1007/978-981-130399-9

26. Margaretha, M., Saragih, S., Zaniarti, S., \& Parayow, B. (2021). Workplace spirituality, employee engagement, and professional commitment: A study of lecturers from Indonesian universities. Problems and Perspectives in Management, 19(2), 346-356. https://doi.org/10.21511/ ppm.19(2).2021.28

27. Mellahi, K., \& Budhwar, P. S. (2010). Introduction: Islam and human resource management. Personnel Review, 39(6), 685-691. https://doi. org/10.1108/00483481011075558

28. Miles, D. (2017). A Taxonomy of Research Gaps: Identifying and Defining the Seven Research Gaps. Retrieved from https:// www.researchgate.net/publica- 
tion/319244623_ARTICLE_Research_Methods_and_Strategies_ Workshop_A_Taxonomy_of_Research_Gaps_Identifying_and_Defining_the_Seven_Research_Gaps

29. Miswanto, M., Arifin, R., \& Murniyati, D. (2020). Does work commitment mediates the effect of Islamic work ethic on performance and turnover intention? JEMA: Jurnal Ilmiah Bidang Akuntansi Dan Manajemen, 17(2), 169-187. https:// doi.org/10.31106/jema.v17i2.5533

30. Mohammad, J., Quoquab, F., \& Salam, Z. A. (2015). Islamic work ethic: An agenda for future research. Advanced Science Letters, 21(6), 1811-1814. https://doi.org/10.1166/ asl.2015.6122

31. Nasution, F. N., \& Rafiki, A. (2020). Islamic work ethics, organizational commitment and job satisfaction of Islamic banks in Indonesia. RAUSP Management Journal, 55(2), 195-205. https://doi.org/10.1108/ RAUSP-01-2019-0011

32. Özpehlivan, M., Acar, A. Z., \& Halsall, J. (rev.ed.). (2016). Development and validation of a multidimensional job satisfaction scale in different cultures. Cogent Social Sciences, 2(1), 1237003. https://doi.org/ 10.1080/23311886.2016.1237003

33. Ramalu, S. S., \& Rashid, M. Z. (2017). Islamic Work Ethic, Employee Engagement And Organizational Citizenship Behaviour: A Study Among Civil Servants In Malaysia. Journal of Global Business and Social Entrepreneurship (GBSE), 1(2), 4355. Retrieved from http://www.gbse. com.my/v1no2jan17/Paper-24-.pdf

34. Rameshkumar, M. (2020). Employee engagement as an antecedent of organizational commitment - A study on Indian seafaring officers. Asian Journal of Shipping and Logistics, 36(3), 105-112. https://doi. org/10.1016/J.AJSL.2019.11.003

35. Rana, H. M., \& Malik, S. M. (2016). Human resource management from an Islamic perspective: a contemporary literature review. International Journal of Islamic and Middle Eastern Finance and Management, 9(1), 109-124. https://doi.org/10.1108/ IMEFM-01-2015-0002

36. Rawwas, M. Y. A., Javed, B., \& Iqbal, M. N. (2018). Perception of politics and job outcomes: moderating role of Islamic work ethic. Personnel Review, 47(1), 74-94. https://doi. org/10.1108/PR-03-2016-0068

37. Razimi, M. S. B. A., Noor, M. M., \& Daud, N. M. (2014). The Concept of Dimension in Human Resource Management from Islamic Management Perspective. MiddleEast Journal of Scientific Research, 20(9), 1175-1182. Retrieved from https://www.idosi.org/mejsr/mejsr20(9)14/31.pdf

38. Rich, B. L., LePine, J., \& Crawford, E. R. (2010). Job engagement: Antecedents and Effects on Job Performance. Academy of Management Journal, 53(3), 617-635. https://doi. org/10.5465/amj.2010.51468988

39. Rigdon, E. E., Sarstedt, M., \& Ringle, C. M. (2017). On Comparing Results from CB-SEM and PLS-SEM: Five Perspectives and Five Recommendations. Marketing ZFP, 39(3), 4-16. https://doi.org/10.15358/03441369-2017-3-4

40. Sadozai, A. M., Khan Marri, M. Y., Fakhar Zaman, H. M., \& Nas, Z. (2013). Moderating role of Islamic work ethics between the relationship of organizational commitment and turnover intentions: A study of public sector of Pakistan. Mediterranean Journal of Social Sciences, 4(2), 767-775. Retrieved from https:// www.mcser.org/journal/index.php/ mjss/article/view/266

41. Saks, A. M. (2006). Antecedents and consequences of employee engagement. Journal of Managerial Psychology, 21(7), 600-619. https://doi. org/10.1108/02683940610690169

42. Salanova, M., Agut, S., \& Peiró, J. M. (2005). Linking organizational resources and work engagement to employee performance and customer loyalty: The mediation of service climate. Journal of Applied Psychology, 90(6), 1217-1227. https://doi. org/10.1037/0021-9010.90.6.1217

43. Shmueli, G., Sarstedt, M., Hair, J. F., Cheah, J. H., Ting, H., Vaithilingam, S., \& Ringle, C. M. (2019). Predictive model assessment in PLS-SEM: guidelines for using PLSpredict. European Journal of Marketing, 53(11), 2322-2347. https://doi.org/10.1108/ EJM-02-2019-0189
44. Sinaulan, J. H., Noor, J., \& Wildan. (2017). Interactive Effect of Motivation, Job Satisfaction, and Job Performance Causal Circular Studies on Sharia Financial Institutions. International Journal of Economic Research, 14(14), 157-167.

45. Spector, P. (1997). Job Satisfaction: Application, Assessment, Causes, and Consequences. SAGE Publications, Inc. https://doi. org/10.4135/9781452231549

46. Sreejesh, S., Mohapatra, S., \& Anusree, M. R. (2014). Business Research Methods: An Applied Orientation. Springer International Publishing. https://doi.org/10.1007/978-3-31900539-3

47. Syed, J., \& Ali, A. J. (2010). Principles of employment relations in Islam: A normative view. Employee Relations, 32(5), 454-469. https://doi. org/10.1108/01425451011061630

48. Wahab, M., \& Masron, T. A. (2020). Towards a core Islamic work value: Evidence from Islamic legal texts and the muftīis verification. Journal of Islamic Accounting and Business Research, 11(1), 179-200. https://doi. org/10.1108/JIABR-11-2017-0158

49. Yongxing, G., Hongfei, D., Baoguo, X., \& Lei, M. (2017). Compromiso con el trabajo y rendimiento en el trabajo: el papel moderador del apoyo organizacional percibido. Anales de Psicología, 33(3), 708713. (In Spanish). http://dx.doi. org/10.6018/analesps.33.3.238571

50. Yousef, D. A. (2000). Organizational commitment: A mediator of the relationships of leadership behavior with job satisfaction and performance in a non-western country. Journal of Managerial Psychology, 15(1), 6-24. https://doi. org/10.1108/02683940010305270

51. Yousef, D. A. (2001). Islamic work ethic: A moderator between organizational commitment and job satisfaction in a cross-cultural context. Personnel Review, 30(2), 152-169. https://doi. org/10.1108/00483480110380325

52. Zeuch, M. (2016). Handbook of Human Resources Management ( $1^{\text {st }} \mathrm{ed}$.). Springer, Berlin, Heidelberg. Retrieved from https://www.springer. com/gp/book/9783662441510 